\title{
Journey Towards Recovery: Insolvency \& Bankruptcy Code of India - A Mirage or a Milestone?
}

\author{
Sunita Chaki, Kshamta Chauhan, Anita Daryal
}

\begin{abstract}
According to a report published by Bankruptcy Law Reforms Committee (BLRC) in Nov 2015, India is amongst those countries which take the longest time to resolve bankruptcy cases at the highest cost. For India, which has a very high concentration of promising entrepreneurs, a speedy resolution for failing corporates is a necessity to create a congenial environment for credit growth and investments in the economy. Addressing NPAs with appropriate recovery mechanisms is as vital as mitigating them at pre-remedial stage. With a brief on the existing recovery mechanisms, the present study comprehends the working of IBC and evaluates its performance since its inception along with a discussion on the limitations and challenges present in the mechanism. The study has also concluded that IBC has been able to give a positive impact; it however still needs to be invested with the power of enforceability and needs to be supplemented with a robust auxiliary system. It's just been two years, how effective IBC will be in long term, will also depend on legislature and judiciary playing their entitled role judiciously.
\end{abstract}

Index Terms: Insolvency and Bankruptcy Code, Insolvency Professionals, Liquidation, Resolution Plan, Non-Performing Assets, Operational Creditors, Recovery.

\section{INTRODUCTION}

Bankruptcy issues of Indian companies prior to Insolvency and Bankruptcy Code were being managed by as many as thirteen different laws. With High Court, Company Law Board(CLB), Board for Industrial and Financial Reconstruction (BIFR) and Debt Recovery Tribunals (DRTs) being four divergent legal routes available for creditors and defaulters, it led to countless negotiations, retarded delays, erosion of asset values and inconclusive cases. The economy thus required a legal framework which could override the prevailing challenges thereby boosting the existing credit culture in India

In line with this objective, Insolvency and Bankruptcy Code -2016 (IBC) was seen to be a mechanism which could speed up resolution among stressed entities while mitigating the challenges which earlier recovery mechanisms were struggling with. How far has this IBC faired in this respect is the focus of this study.

The study on IBC is divided into three sections. Giving a very brief background of the existing recovery mechanisms, Section One covers the conceptual and structural working of
IBC. Section Two examines and evaluates the performance of IBC since 2016. Section Three deliberates on the limitations and challenges existing in the present mechanism. It finally concludes with suggestions which could help the IBC mitigate the challenges existing in the mechanism.

Objectives. The objectives of this study are:-

i.To view the conceptual and structural format of Insolvency and Bankruptcy Code (IBC) 2016.

ii.To analyse the performance of IBC.

iii.To examine the limitations present in IBC and suggestions to mitigate them.

\section{Section 1 : Conceptual and Structural Working OF IBC}

\section{A. Background}

The legal recovery framework against loan defaults has not been able to keep up with dynamic changes in commercial transactions and practices in India. This has effectuated an alarming rise in non-performing assets in the banking sector. Understanding the requirement, several legal recovery related reforms were initiated by T.T Tiwari, Narasimhan I \& II and Andhyarujina committee[1].

SICA 1985 was instituted with a focus on rehabilitation of the distressed companies. RDDBFI in 1993, on the other hand, was introduced with an intention to empower the banks and financial institutions with some definitive capability to recover the loans and assets under stress. This was supported by the change in recovery related laws and setting up of special Tribunals with distinctive powers [2].

SARFAESI 2002 further enabled the Banks and Financial Institutions to reduce their non-recoverable loan burden through securitization facilitation. This act empowered the banks to take possession and sell the securities in default cases without recourse to the courts.

Brief details of the existing recovery mechanisms along with the limitations are tabulated as under:-

Revised Manuscript Received on September 25, 2019.

Sunita Chaki, PhD Scholar, Amity University Noida

Kshamta Chauhan, AIBS, Amity University, NOIDA, UP, India.

Anita Daryal, Oriental Bank of Commerce, Delhi, India

${ }^{2}$ IBC reigns supreme over other civil laws:Delhi High Court-Business Standard $23^{\text {rd }}$ 
Journey Towards Recovery: Insolvency \& Bankruptcy Code of India - A Mirage or a Milestone?

\begin{tabular}{|c|c|c|}
\hline \multicolumn{3}{|c|}{$\begin{array}{ll}\text { Figure } \quad-1.1 \\
\text { MECHANISMS }\end{array}$} \\
\hline \multirow[t]{6}{*}{1.} & Act : & $\begin{array}{l}\text { Legal Services Authorities } \\
\text { Act ( Lok Adalats) }\end{array}$ \\
\hline & $\begin{array}{l}\text { Year of } \\
\text { Imple-mentation: }\end{array}$ & 1987 \\
\hline & Eligible Cases: & $\begin{array}{l}\text { All NPAs within limitation } \\
\text { period,even cases at } \\
\text { pre-litigative stages can be } \\
\text { referred. }\end{array}$ \\
\hline & Jurisdiction: & $\begin{array}{l}\text { Decree granted is binding } \\
\text { and cannot be challenged } \\
\text { and is at par with civil } \\
\text { court decree. }\end{array}$ \\
\hline & Procedure: & $\begin{array}{l}\text { Process of voluntary } \\
\text { arbitration, conciliation, } \\
\text { granting of decree by Lok } \\
\text { Adalat. Settlement with } \\
10-20 \% \text { of settlement } \\
\text { amount in lump sum. } \\
\text { Remaining amount } \\
\text { within or up to three years. }\end{array}$ \\
\hline & Limitations: & $\begin{array}{l}\text { Deals with cases } \\
\text { involving small amount. }\end{array}$ \\
\hline \multirow[t]{5}{*}{2 . } & Act : & $\begin{array}{l}\text { RDDBFI (establishing } \\
\text { DRTs ) }\end{array}$ \\
\hline & $\begin{array}{l}\text { Year of } \\
\text { Imple-mentation: }\end{array}$ & Aug 1993 \\
\hline & Eligible cases: & $\begin{array}{l}\text { NPAs with more then Rs } \\
10 \text { lakh. } \\
\text { Claims of banks and } \\
\text { financial instituions only. }\end{array}$ \\
\hline & Jurisdiction: & $\begin{array}{l}\text { No intervention of Civil } \\
\text { courts }\end{array}$ \\
\hline & Limitations: & $\begin{array}{l}\text { - Overburdened } \\
\text { DRTs - leading to } \\
\text { delays. } \\
\text { - Lack of business } \\
\text { and financial } \\
\text { expertise among } \\
\text { the adjudicating } \\
\text { authority }\end{array}$ \\
\hline \multirow[t]{3}{*}{3.} & Act : & $\begin{array}{l}\text { SARFAESI (Provision of } \\
\text { securitisation, } \\
\text { reconstruction } \\
\text { enforcement of secured } \\
\text { assets) }\end{array}$ \\
\hline & $\begin{array}{l}\text { Year of } \\
\text { Imple-mentation }\end{array}$ & June 2002 \\
\hline & Eligible Cases: & NPAs only \\
\hline
\end{tabular}

\begin{tabular}{|l|l|l|}
\hline & underlying secured assets \\
\cline { 2 - 3 } & Jurisdiction: & $\begin{array}{l}\text { No intervention of Civil } \\
\text { courts }\end{array}$ \\
\cline { 2 - 3 } & Time Limit: & $\begin{array}{l}\text { Preferably within } 60+45 \\
\text { days }\end{array}$ \\
\cline { 2 - 3 } & Limitations: & $\begin{array}{l}\text { Not applicable to } \\
\text { creditors } \\
\text { Complications on } \\
\text { execution front. }\end{array}$ \\
\hline
\end{tabular}

Source: Bare Acts 2017-18

The performances of the NPA recovery mechanisms have however been severely affected due to multi fold issues including presence of multiple legal fora, overlapping rules and conflicting resolutions [3]-[5]. This led to complications related to undue delays, absence of strong backup for creditors with minimal legal bindings on borrowers. The presence of these complications and prevalence of multiple regulatory authorities with cross overlapping rules and provisions in the recovery mechanisms, the initiation of IBC was seen to be the best possible option to cater the poor recovery in one go [6].

\section{B. IBC-2016}

Enactment of IBC indicated a clear intent of the regulators to de-stress the banking system. IBC, at a macro level, was expected to improve the credit and compliance culture in the economy. At the micro level, it was to empower creditors, discipline the borrowers and provide an environment for time adhered resolutions for the corporates [7].

The prime objective of IBC was to consolidate, revise and re-establish the insolvency-related laws. The Code was enacted to create an environment to reinvigorate investments and entrepreneurship expanding the credit market thereby leading to growth and development in the economy. Code has also made provisions for amendments in SARFAESI Act, SICA, RDDBFI Act and Companies Act 2013.

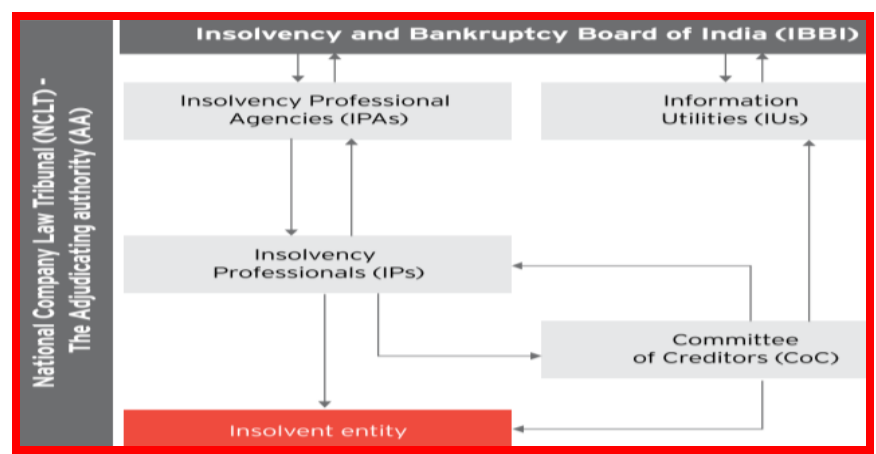

Figure -1.2 Structural Framework of IBC

Source: www.ey.com (Earnst and Young) 


\section{Structure of IBC}

IBC established in Dec 2016, was armed with a robust structure of regulators, a strong legal framework, and skilled service providers. Insolvency and Bankruptcy board of India (IBBI), the regulatory body, got instituted to regularise and supervise the system. NCLTs, DRTs \& appellate bodies built the legal framework. The service providers, having Insolvency Professionals, Information Utility and Registered Valuers act as a support system in smooth functioning of the system [8].

The structural framework of IBC as shown in the figure indicates various linkages and interactions among each functionary with others. The day to day working and the ongoing resolution proceedings of the insolvent entity, for instance, is monitored by Insolvency professionals (IPs) who eventually are accountable to Insolvency professional agencies (IPAs) and IBBI. Likewise, during the resolution meetings of Committee of Creditors (COCs), Information utilities (IUs) act as a link between information seekers and providers, to authenticate, and verify information exchanged among COCs and IPs. The overall supervision and formal approval of resolution proceedings is done by adjudicating authority (NCLTs). A brief of these interlinked functionaries are as follows:-

i. IBBI, a link between the government and other functionaries of IBC, got instituted on $1^{\text {st }}$ Oct 2016. Being supervisory in nature it directs, regulates, consolidates and amends the laws related to insolvency and bankruptcy[9]. The IBBI board also supervises Insolvency Professional Agencies (IPAs) \& Insolvency Professionals (IPs), adjudicating authorities (NCLT \& DRTs), professional entities including information utility \& registered valuers for efficient functioning of Insolvency Mechanism [10].

ii. NCLTs and DRTs acts as the adjudicating authorities to steer the whole resolution process. NCLT is authorised to deal with cases related to companies and Limited Liability Partnerships (LLPs) whereas DRTs supervise and conclude Partnership Firms and individual related cases. Established on $1^{\text {st }}$ June 2016, NCLTs got instated as per Companies Act 2013. It is a quasi-judicial body with competency to adjudicate disputes, related to corporate civil cases. NCLT has the authority to sanction admission of such cases and expedite in such a manner specified in IBC. Eleven NCLT benches have been set up all over India[8]. The objective of establishing NCLT is to provide a single window resolution mechanism, bypassing High Courts so as to conclude cases in a more efficient, speedy and effective manner .

iii. Among the service providers, Insolvency Professionals (IPs) are one of the founding pillars on which success of the mechanism is balanced. The function of IPs is to oversee the day to day functioning of the entities under resolution, coordinate the meeting of COCs, consolidate and verify the assets of stressed entities and process the liquidation as and when required [11]. The IPs are also required to report the status of proceedings to adjudicating authorities and IBBI.

iv. Information utility (IU) another key pillar was established on $25^{\text {th }}$ Sep 2017. The National
E-Governance Service Limited (NESL), is the functioning information utility under IBBI Regulation act 2017. The NESL acts as a storehouse of financial information and is competent authority in establishing defaults and substantiating the claims of the stakeholders. It also provides and authenticates information required by IPs to maintain transparency and smooth functioning for insolvency or bankruptcy proceeding registered in NCLT or DRTs [12].

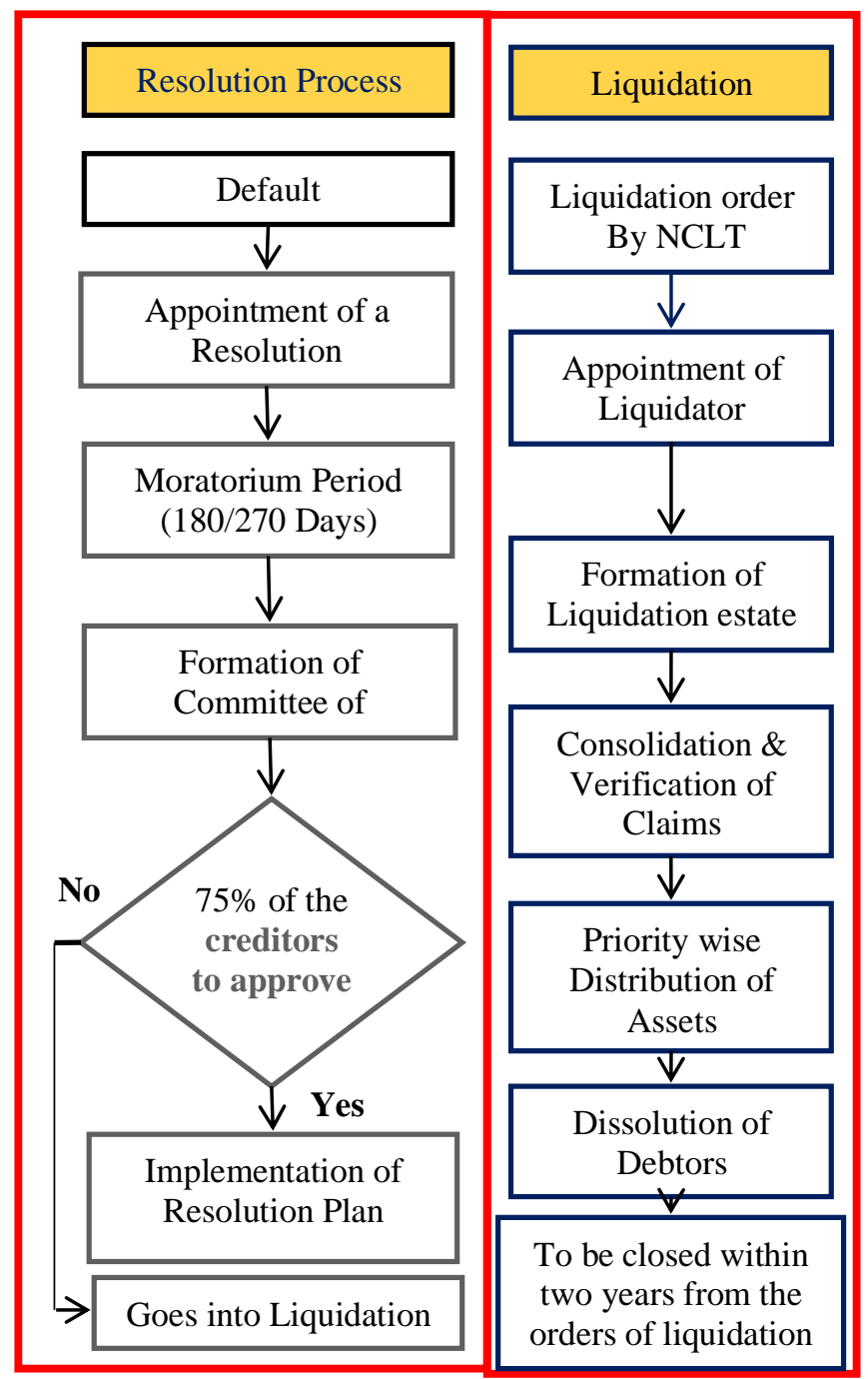

Figure -1.1 Working Under IBC-2016 Source: www.ey.com (Earnst and Young) 


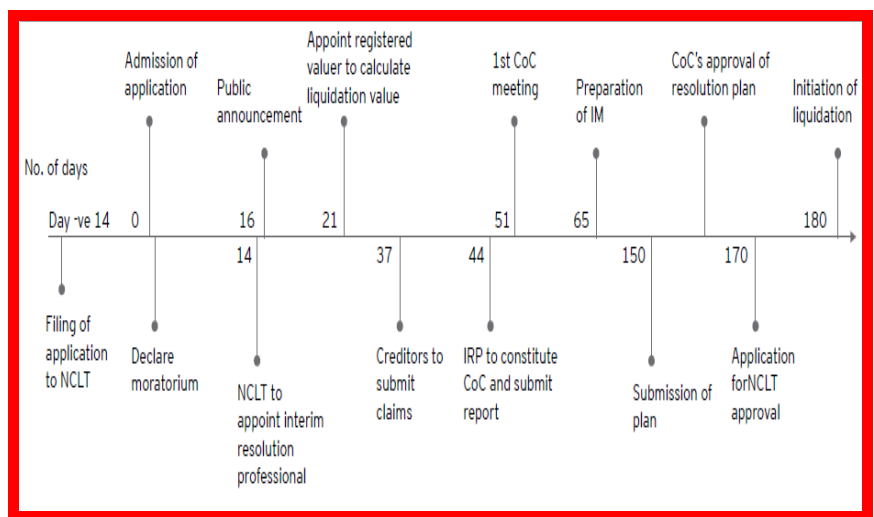

Figure -1.2 Timeline of CIRPS Under IBC 2016

Source: www.ey.com (Earnst and Young)

\section{Section 2 : Performance Evaluation}

With the system set in its place, the recovery mechanism under IBC started with a positive note. Some of the landmarks in the functioning of IBC are as given below[13]:-

\section{Landmark IBC Cases \\ $\underline{\text { Year }}$ \\ First application filed in NCLT 17-01-2017 Mumbai- Innoventive Industries Ltd.}

\begin{tabular}{l}
$\begin{array}{l}\text { First application filed by } \\
\text { FC-Innoventive Industries Ltd. }\end{array}$ \\
$\begin{array}{l}\text { First application filed by CD- UB } \\
\text { Engineering Ltd. }\end{array}$ \\
$\begin{array}{l}\text { First application filed by OC-Midas } \\
\text { Touch Export Pvt. Ltd }\end{array}$ \\
\hline $\begin{array}{l}\text { RBI's Mandate to intiate CIRP against } \\
\text { 12 Big defaulters }\end{array}$ \\
\hline $\begin{array}{l}\text { First approved resolution plan } 2017 \\
\text { Synergies Dooray Automative Ltd }\end{array}$ \\
$\begin{array}{l}\text { First approved Liquidation- Bhupen } \\
\text { Electronic Ltd }\end{array}$ \\
\hline $\begin{array}{l}\text { First 100\% recovery against claims } \\
\text { filed Prowess International Pvt Ltd }\end{array}$ \\
\hline
\end{tabular}

Source Various Newsletter ,IBBI

Figure -2.1 Landmark IBC Cases

It is just been about two years since the mechanism has been operational wherein, a total of 1484 cases have been admitted so far. Out of these admitted cases, 142 cases got resolved under Appeals/ Reviewed/Settled category, 63 withdrawn under section 12A, 79 were resolved under resolution Plan, and 302 cases have been approved for liquidations [14].

Looking at the overall performance of all cases admitted so far, out of 1484 cases, a total of 586 were resolved under different categories by end of Dec 2018. Out of these resolved cases, $13 \%$ (79/586) have been resolved under resolution plan whereas as much as 52\% (302/586) underwent liquidation.

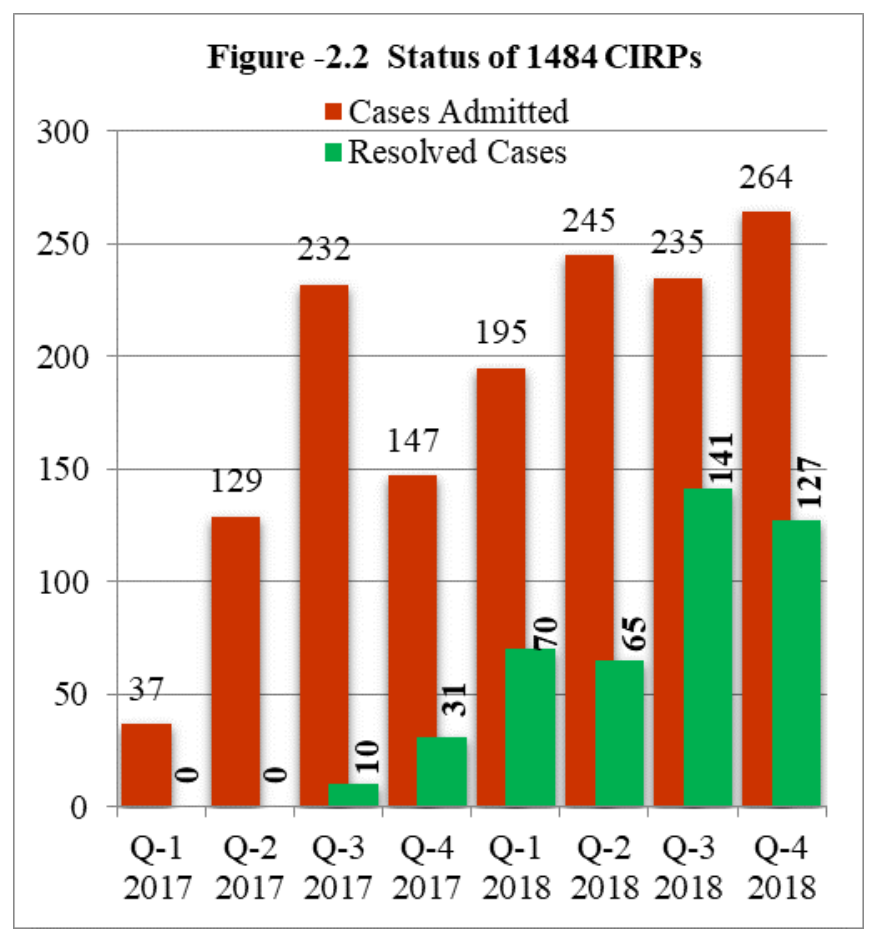

Source: Data retrieved from www.ibbi.gov.in

D. IBC-An Improvement over Existing Mechanisms

Comparative performance of recovery from Lok Adalats, SARFAESI and DRTs taken together vs performance of IBC, indicates that the IBC has taken off with $41.3 \%$ and $46.1 \%$ recoveries against the cases filed, registering an impressive start.[15]

Figure-2.3 Average Recovery From Various Channels

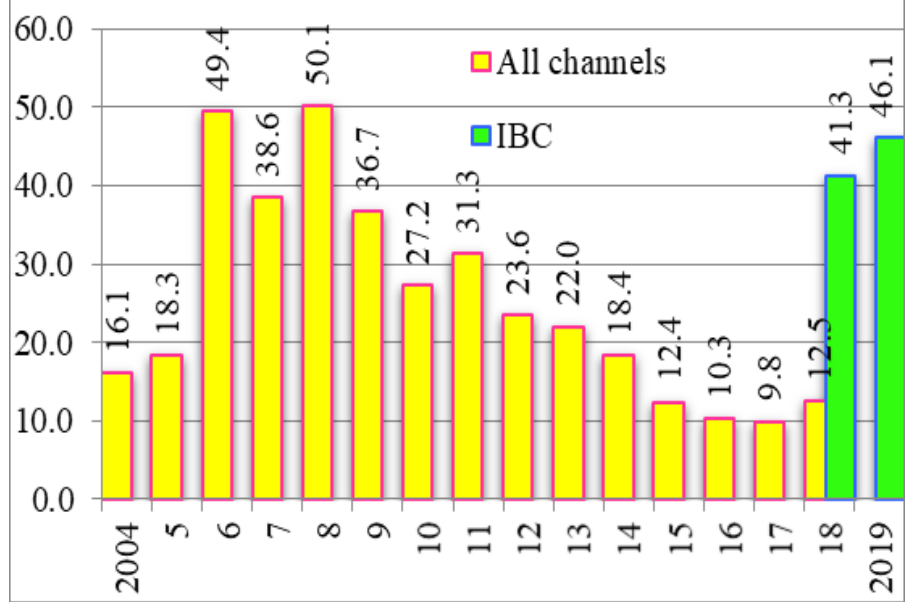

Source: Trend and Progress 2017-18,RBI

IBC has been able to improve upon the existing mechanism in following ways.

i.A Conducive Environment of Credit Culture. The IBC has been able to create an environment which has proved to be a deterrent for the borrowers to default[16]. 
ii.According to the Finance Minister, 3300 cases amounting approximately Rs 2 lakh crores were recovered by stressed companies ${ }^{3}$ before being brought under NCLT [17]. The amount realised under resolution process is about Rs 60,000 crores which is more than $202 \%$ amount of its liquidation value. The credit disbursement (in non-food items) has also recorded a rise to Rs 13195.20 crores in first half of 2018-19 from Rs 4952.24 Crores in 2016-17.

iii. Shift in Accountability. Prior to IBC, the creditors were tied up with complex and complicated procedures which costed them in terms of time and money[18]. The defaulting borrowers are now accountable and accordingly, procedures for creditors have been simplified. The final judgment in Swiss Ribbons Pvt. Ltd. \& Anr. vs Union of India \& Ors WRIT PETITION (CIVIL) NO. 99 of 2018. Supreme court of India in Jan 2019 stated that with the initiation of IBC, "The defaulters paradise has been lost. In its place economy's rightful position has been regained".

iv. Reshuffling of Creditors Priority Claims and Expansion of Creditors List. Contrary to earlier times when govt dues were given priority, financial creditors are given higher priority under IBC [20]. It has also broadened up the list of creditors who could file the claims before NCLT. In earlier times, the operational creditors couldn't get the defaulters declared insolvent, IBC empowered them seek this remedy ${ }^{4}$. This incentive made the operational creditors file as many as 742 out of the total 1484 case filed so far $(50 \%)$.

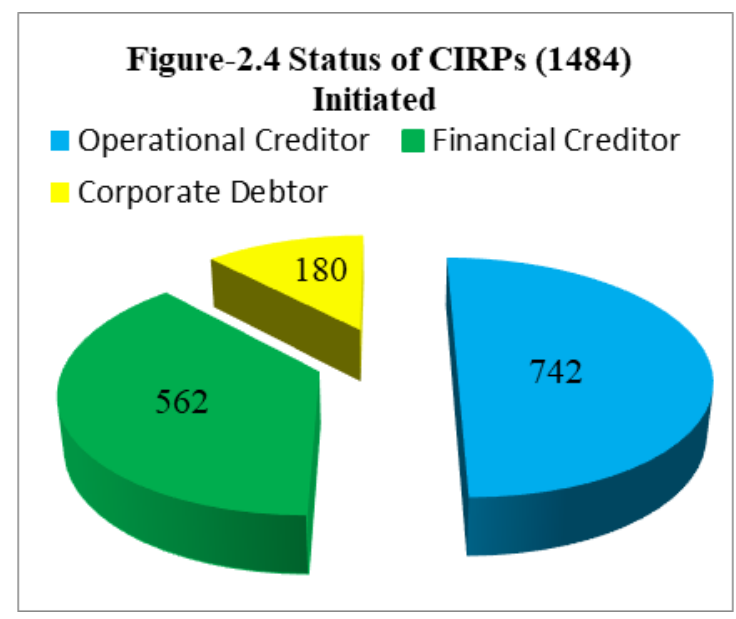

Source: Data retrieved from IBBI Newsletter 2016-18

v. Professional Auxiliary Mechanism. The regulators have made an effort to strengthen structure of the mechanism by providing 38 DRTs and 15 NCLT benches along with 2287 skilled professional IPs, who play a major role in successful closure of cases.

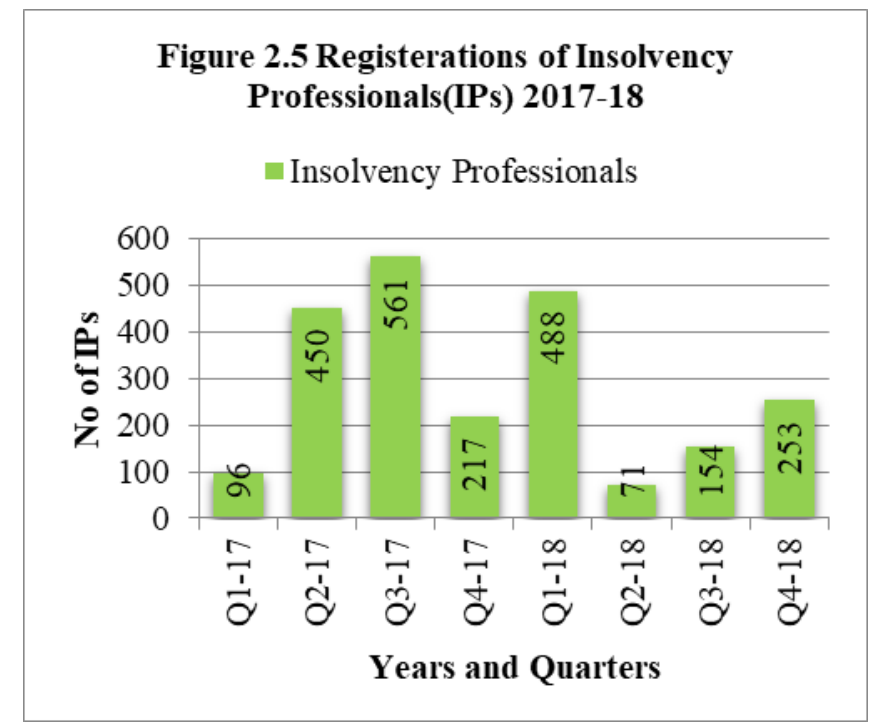

Source: Data retrieved from IBBI Newsletter 2016-18

vi. Unified Code. IBC has been one single mechanism which is dealing with all distressed entities without having overlapping and contradictory laws as was the case in earlier mechanisms[21]. To manage this objective, as many as eleven laws have been amended or repealed. These include amendments in RDBA 1993(erstwhile RDDBFI-1993) and SARFAESI 2002 and Company Act 2013.

vii. Stress Reolution under Large Borrowal Account. The twelve largest defaulters which contributed to $25 \%$ of NPAs were admitted under the directions of RBI in June 2017.

Figure-2.6 Resolution of Twelve Big Defaulters

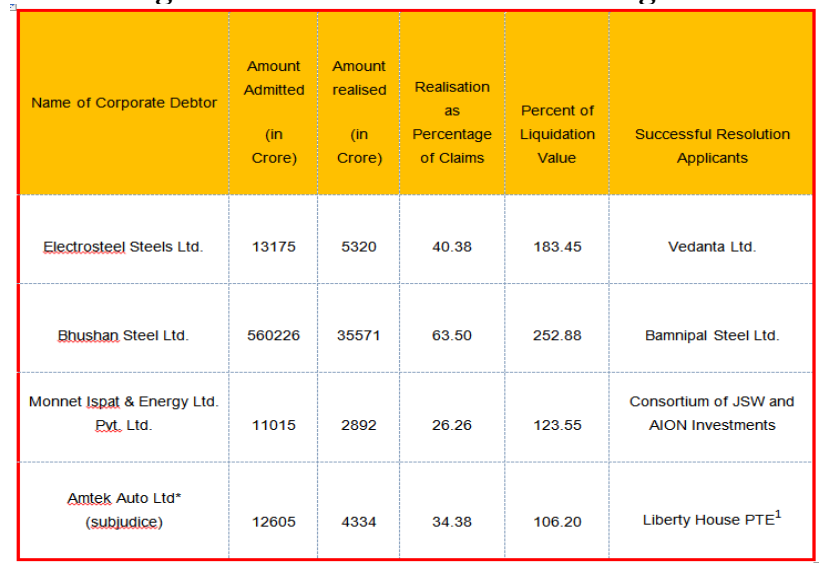

Source: Data retrieved from Quarterly Newsletter of IBBI, Oct - Dec, 2018 | Vol. 9

Four cases has been resolved under Resolution plan and one case of Lanco Infratech Ltd been approved for liquidation. Rest of the cases being under process, have an outstanding claim of 3.45 lakh and liquidation value amounting to Rs 73220.23 Crores [22]. 


\section{Section 3 : Limitations / Challenges of IBC}

Notwithstanding the areas of improvements brought in by the new Code, there are certain concerns which need regulatory attention.

A. Pending Cases Beyond Time Limit. The first area of concern is the pending cases which haven't adhered to the time prescribed under IBC. Since the last eight quarters number of pending has been on rise. By Dec 2018 the pending cases before NCLT has been accumulated to 898 out of the total of 1484 cases admitted so far. Time adherence analysis of undermentioned three categories has been carried out.
i. Resolved cases.
ii. Undergoing cases.
iii. Voluntary Liquidation cases.

B. Status of Time Adherence of 'Resolved Cases'. Given the permissible limit of 180 plus 90 days in Oct-Dec 2017 quarter, 10 cases were resolved out of which seven cases were successfully closed within time limit. In subsequent four quarters the percentage of the cases crossing the time limit increased to $100 \%$ where all 13 cases [22] were resolved beyond the 270 days limit. This isn't an encouraging trend.

\begin{tabular}{|c|c|c|}
\hline \multicolumn{3}{|c|}{$\begin{array}{l}\text { Figure-3.0 Time line Status of Resolved Cases Under } \\
\text { Resolution Plan }\end{array}$} \\
\hline Qr /Year & Resolved Cases & $\begin{array}{l}\text { Resolved Beyond } 270 \\
\text { Days }\end{array}$ \\
\hline Oct-Dec 2017 & 10 & 3 \\
\hline Jan-Mar 2018 & 12 & 6 \\
\hline Apr-Jun 2018 & 12 & 9 \\
\hline Jul-Sep 2018 & 35 & 29 \\
\hline Oct-Dec 2018 & 13 & 13 \\
\hline
\end{tabular}
Source: www.ibbi.gov.in

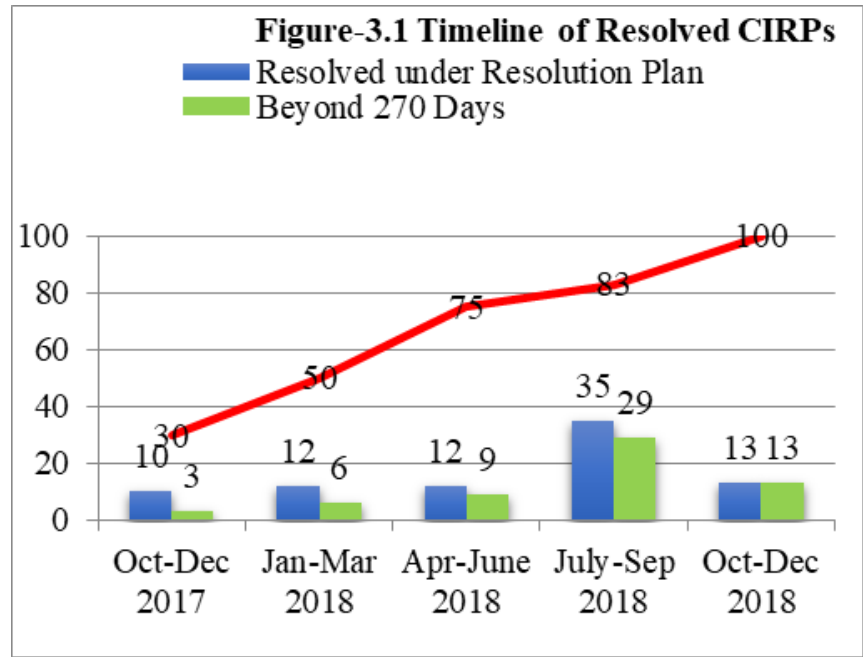

Source: Data retrieved from www.ibbi.gov.in

A. Timeline Status of 'Ongoing Cases'. The number of cases which have exceeded the time limit $^{5}$ of 270 days are as much as $30.6 \%$ (275 out of 898 ongoing cases). Looking at the timeline status of resolved cases, the probability of the 166 cases crossing the timeline cannot be ruled out.

\begin{tabular}{|ll|}
\hline $\begin{array}{l}\text { Twelve Defaulters (RBIs First } \\
\text { list)* }\end{array}$ & $\begin{array}{l}\text { Duration of CIRPs } \\
\text { (As on Nov2018) }\end{array}$ \\
\hline Bhushan Steel & 293 (resolved) \\
\hline Essar Steel India & 457 (Ongoing) \\
\hline Bhushan Power \&steel & 464 (Ongoing) \\
\hline Alok Industries & 472 (Ongoing) \\
\hline ABG Shipyard & 458 (Ongoing) \\
\hline Electrosteel Steels & 270 (resolved) \\
\hline Amtek Auto* & 366 (Ongoing) \\
\hline Monnet Ispat \& Energy & 371 (resolved) \\
\hline Jyoti Structures & 486 (Ongoing) \\
\hline Lanco Infratech & 452 (Ongoing) \\
\hline Jaypee Infratech & 450 (Ongoing) \\
\hline Era Infra Engineering & 178 (Ongoing) \\
\hline
\end{tabular}

Figure-3.2 List of Twelve Biggest Defaulters

* Resolution *Applicant Failed to comply Source: ICRA Research, Business Standard News Dec2018

Figure-3.3 Timeline of Ongoing CIRPs (898) - Ong oing CIRP

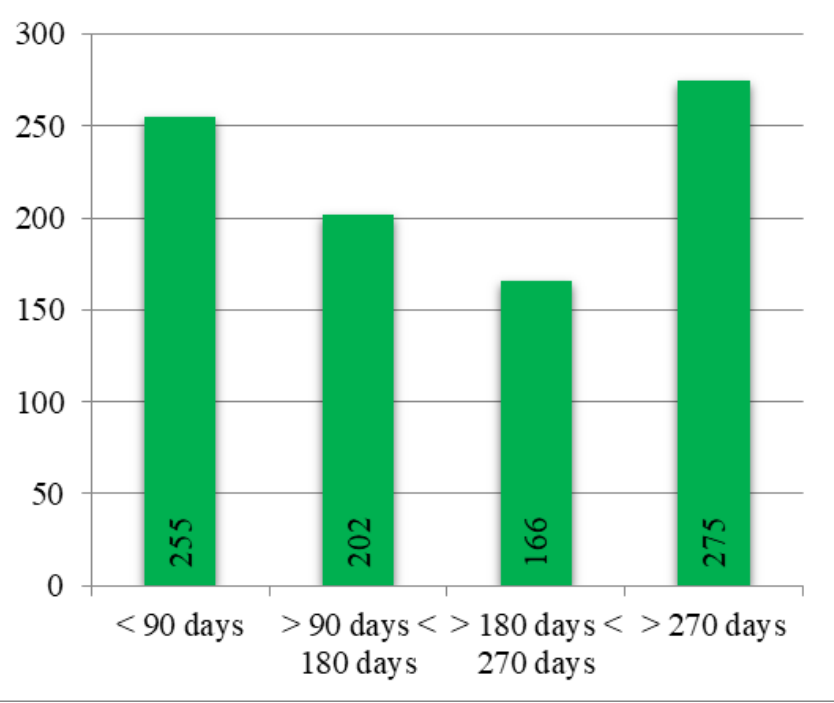

Source: Data retrieved from www.ibbi.gov.in

A. Timeline Status of 'Voluntary Liquidations'. The status of voluntary liquidation wherein the time prescribed to be two years, out of the 246 cases filed under volunatry liquidations by Dec 2018, 68 cases have already crossed more than 360 days mark (IBBI, 2017a, 2017b, 2018c, 2018b \& 2018a). 


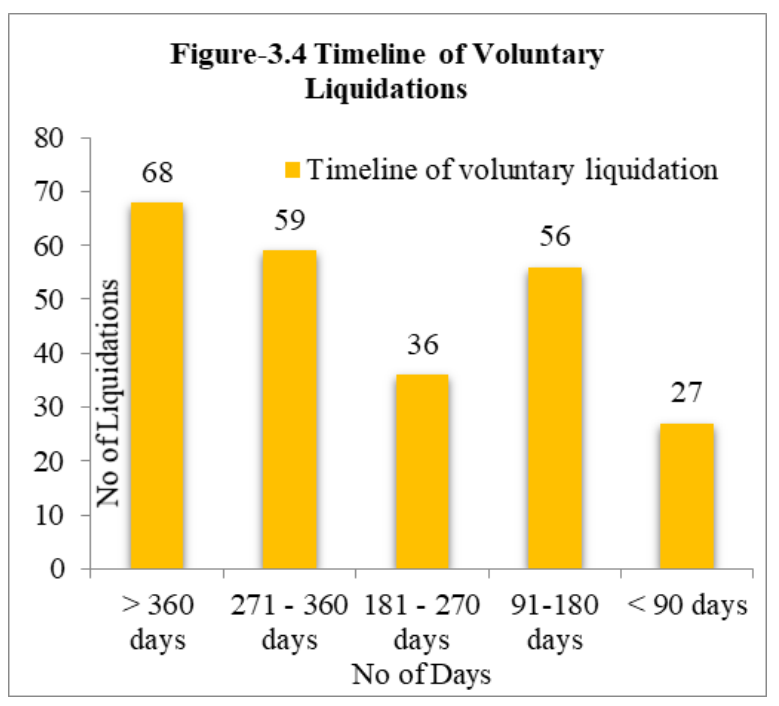

Source: Data retrieved from IBBI Newsletter Oct-Dec 18

The definitive evaluation on these cases though can only be done with the passage of time, still major focus of IBC being said to be the 'time adherence in the cases', regulators need to be watchful in this area as well. Problem of adherence of time resolved, ongoing and voluntary cases is an indication of existence of loopholes related to amendments, infrastructural requirements, and regulatory scrutiny.

A.Bias Towards Liquidations ${ }^{6}$. The second point of concern is related to the proportion of 'closed cases under resolution plan' and under 'liquidation'. Out of a total of 586 resolved cases, only $13 \%$ i.e 79 cases are resolved under resolution plan compared to $52 \%$ (302) which got the orders for liquidation. This concern may however be diluted on the pretext that the cases subjected to liquidation are majorly either defunct corporates or were under BIFR/AAIFR cases registered under SICA 1985. And thus bringing them under resolution plan would not have worked anyways.

However, if we examine the share of net liquidated cases excluding defunct or BIFR referred cases, the share of liquidations seems to have come down.

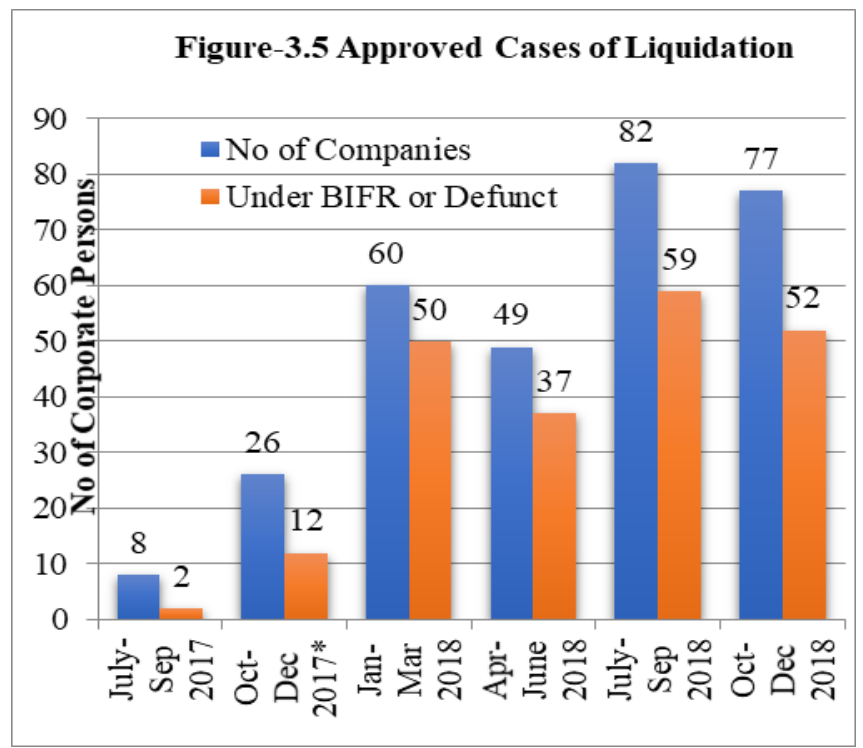

Source: Data retrieved from IBBI Newsletter 2016-18

${ }^{6}$ Detailed Liquidation rules to save viable Firms says IBBI Chairmen-Business Standard $11^{\text {th }}$ March 2019

\section{Figure-3.6 Comparision of Cases Closed excluding BIFR cases}

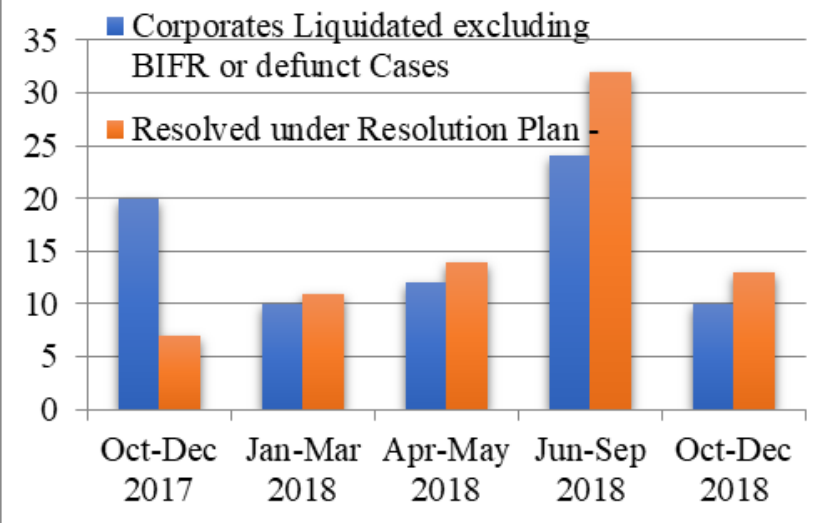

Source: Data retrieved from IBBI Newsletter 2016-18

The percentage closure of cases under Resolution Plan has increased by 1.04 times more than the Liquidations. This trend, however, still needs to be watched since the cases under liquidation is high and this trend if continued for a longer period of time may not be in public interest and economy as a whole.

B. Recoveries by Financial Creditors. The trend in the recovery realised against claims filed by financial creditors quarter wise analysis delivered mix responses. The results in the first quarter were not encouraging recording an average of $32 \%$ recoveries. The lowest recovery by financial creditors was recorded during Jun-Sep 2018 quarter with a 26\% recovery[14]. This however improved in the subsequent quarter with an average of $90 \%$ claims realised in Oct-Dec 2018 quarter.

Figure-3.7 Recovery By Financial Creditors

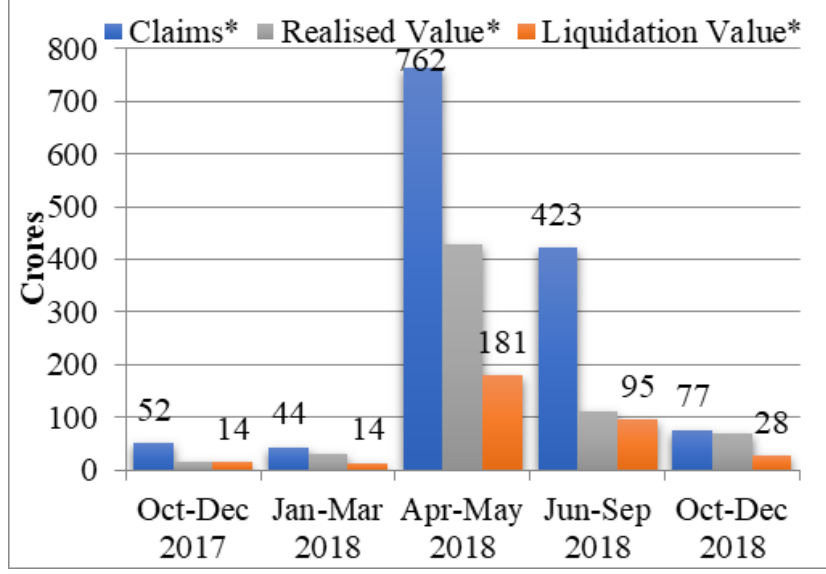

Source: Data retrieved from www.ibbi.gov.in

Overall recovery of all quarters taken together was $46 \%$ [15]. Looking at the trend of other recovery mechanisms the comparative performance happens to be significantly high. 
C. Infrastructural Inefficiencies. Since December 2016, as many as 10,000 cases have been filed against 1484 cases registered in 13 active NCLTs benches ${ }^{7}$. Though the cases admitted are significantly low but looking at the pace at which the cases are being filed and the amount of NPAs present in the economy, it is not too long that the cases filed would also increase by leaps and bounds. A meagre 13 NCLTs won't be able to cope up with the future demand pending NPAs related cases. Even in cases of partnerships firms and individuals where DRTs are assigned to be the adjudicating authorities haven't been notified or made operational till date.

\section{SugGestions}

A. Identification of Common Objectives. Looking from a broader perspective, IBC is based on some concrete and focal objectives. The institutional objectives of the government, the RBI and the banks, however differ and thus may not coincide with the objectives underlined while enacting or operationalising the IBC mechanism. The government, for example, having an objective of 'in the larger public interest ${ }^{8}$, the Banks to have "early resolutions' 9 while the RBI may stress on banks to maintain stability ${ }^{10}$ in the economy. These objectives may clash at times leading to limiting its effectiveness in the long term ${ }^{11}$. Thus it is important to identify the common objectives for enhancing efficacy of IBC.

B. Empowerment. At a micro level the recovery mechanisms needs to be adequately empowered. It needs to be empowered with respect to its ability to identify the genuine stressed accounts from a wilful default. The way law deals with wilful defaults would prove to be a deterrent for the further defaults and genuinely stressed accounts will still get an option to get restructured or reorganised. This would also lead to a positive shift in the tendency of banks not to be risk aversive towards the whole industry.

C. Infrastructure. Likewise the mechanism also needs to be sufficiently equipped with adequate infrastructure, skilled personal and robust information dissemination system. The IBC till now has been seen to be fully equipped but looking at the over 10000 cases filed to be registered, it would be requiring an extension of the infrastructure $^{12}$.

\section{CONCLUSION}

Any legislation dealing with economic matter is bound to face practical problems which are highly complicated and thus cannot be solved with one strait jacket formula. On a positive side, IBC seems to have managed and countered certain recovery related challenges by instituting NCLTs, providing skilled service providers, empowering the

\footnotetext{
${ }^{7}$ How solvent is insolvency code Business Standard news- 19 Jan 2019

${ }^{8}$ In case of SICA 1985 where the stress on rehabilitation of non-viable entities was enforced, it being in the public interest

9 Sale of assets to ARCs leading to abrupt and unaccounted spurt in 2016

${ }^{10}$ Asset classification and provisioning norms mentioned in 12th feb 2018 revised framework and stringent norms for the banks selling the assets to ARCs in April 2014.

${ }^{11}$ Schemes like S4A,SDRs,5:25 were used more for ever greening then for genuine reasons

${ }^{12}$ How solvent is Insolvency act -Business Standard News19th Jan 2019
}

creditors, restricting the frivolous litigations and prompt amendments in IBC. This has helped build a constructive environment of credit culture leading to credit expansion in the economy. The significant recovery made through IBC is a clear indication that IBC has proved to be a deterrent for future defaults and has also helped the lenders with an improved recovery.

IBC however still have certain functional limitations. Ignoring the embryonic problems, judicial ambiguities in the form of misinterpretation of laws, conflict of objectives among different stakeholders are also contributing to delays in timely resolutions. Besides this, the performance of IBC mechanism is inflicted with age old problem of infrastructural insufficiency.

Analysing the significant number of insolvency applications filtered out at filing stage, the volatile pattern of recoveries against the claims filed, and the mechanism faltering on prescribed timeline, the apprehension of IBC falling in the same trap as its predecessors, cannot be ruled out.

The limitations needs to be addressed by supplementing an auxiliary mechanism to relieve the overburdened NCLTs on one hand and on the other hand, empowering the IPs who evidently work against the vested interest of promotors and directors of the insolvent entities .

The success of IBC thus depends on how quickly the regulators acknowledge and respond to the prevailing deficiencies in the recovery system. The degree of responsiveness towards the required changes in recovery mechanism will only decide whether IBC will prove to be a milestone or a mirage in the history of recoveries among stressed entities in India.

\section{REFERENCES}

1. D. Kapur and R. Ramamurti, "Working Paper No . 142 Privatization in India : The Imperatives and Consequences of Gradualism by Policy reform in India," no. 142, 2002.

2. S. Visaria, U. von Lilienfeld-Toal, and D. Mookherjee, "The Distributive Impact of Reforms in Credit Enforcement: Evidence from Indian Debt Recovery Tribunals," Econom. Soc. Publ., vol. 80 no. 2, pp. 497-558, 2012.

3. H. Bhojani et al., The Scheme of Arrangement as a Debt Restructuring Tool in India : Problems And Prospects, no. ii. 2018.

4. N. Kang and N. Nayar, "The Evolution of Corporate Bankruptcy Law in India," ICRA Bull. Money Financ., no. October 3-March 3, pp. 37-58, 2003.

5. A. Ravi, "Indian Insolvency Regime in Practice An Analysis of Insolvency and Debt Recovery Proceedings," Econ. Polit. Wkly., vol. 1, no. 51, 2015.

6. E\&Y, "Interpreting the Code Corporate Insolvency in India," Ernst andYoung, 2017.

7. E\&Y, "Insolvency and Bankruptcy Code," Vidhi Cent. Leg. Policy, vol. 1, no. December, 2018

8. IBBI, "Insolvency and Bankruptcy News," The Quarterly Newsletter of the Insolvency and Bankruptcy Board of India., vol. 1, no. Dl, pp. $1-12,2016$.

9. IBBI, "Insolvency Profession:An institution in the making," The Quarterly Newsletter of the Insolvency and Bankruptcy Board of India, vol. 6, 2018.

IBBI, "Insolvency and Bankruptcy News-Balancing the interests of Stakeholders," The

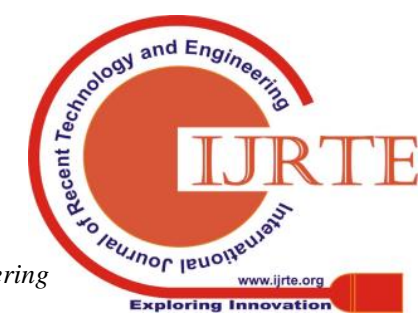


Quarterly Newsletter of the Insolvency and Bankruptcy Board of India July-Sep 2017, vol. 4, 2017.

11. A. Ravi, "Indian Insolvency Regime in Practice An Analysis of Insolvency and Debt Recovery Proceedings," 2015.

12. IBBI, "Insolvency and Bankruptcy News-COC Dharma," The Quarterly Newsletter of the Insolvency and Bankruptcy Board of India, vol. 7, no. June, 2018.

13. IBBI, "Insolvency and Bankruptcy News-Insolvency Resolution Process," The quaterly Newletter of IBBI Oct-Dec 2017, 2017.

14. IBBI, "Insolvency and Bankruptcy News-Automating the wheels of Commerce," The Quarterly Newsletter of the Insolvency and Bankruptcy Board of India J, vol. 8, 2018.

15. Reserve Bank of India, "Report on Trend and Progress of Banking in India 2017-18,” 2018.

16. IBBI and A. Jaitely, "Insolvency and Bankruptcy Code," in Insolvency and Bankruptcy: Changing Paradigm, 2017, no. August.

17. A. Jaitley, "Two years of insolvency and Bankruptcy Code (IBC)," Facebook, 2019.2 [Online]. Available: https://www.facebook.com/notes/arun-jaitley/two-years-of-insolvenc y-and-bankruptcy-code-ibc/938314493023766/.

18. R. Thomas and R. K. Vyas, "Loan recovery strategy in Indian banks," Int. J. Commer. Manag. Res., vol. 2, no. 12, pp. 158-164, 2016.

19. Swiss Ribbons Pvt. Ltd. \& Anr. V Union of India \& Ors WRIT PETITION (CIVIL) NO. 99 OF 2018. Supreme court of India. 2019, pp. 1-150.

20. K. V.A. N. Zwieten, "Corporate Rescue in India: The Influence of the Courts,” J. Corp. Law, vol. 5970, no. April, pp. 1-32, 2015.

21. A. Jaitley, "Insolvency and Bankruptcy Code, 2016: A Roadmap for the Next Two Years," 2018.

22. IBBI, "Insolvency and Bankruptcy News-Shepherding Valuation Profession," The Quarterly Newsletter of the Insolvency and Bankruptcy Board of India, vol. 9, 2018.

23. M. S. Sahoo, "Banking on Governance-Freedom From and Freedom To,” Indian Inst. Bank. Financ., pp. 1-9, 2017.

\section{AUTHORS' PROFILE}

Sunita Chaki, Ph.D Scholar at Amity University, Noida. She has also published papers on „Indian Banking - Challenges, Reforms and Road Ahead"e in the International Journal of Banking, Risk and Insurance and „On the Roads to Recovery : How Far to Go? ${ }^{\text {ee }}$ in Indian Journal of Economics and Business.

Kshamta Chauhan, an Associate Professor in Amity University Noida, has a teaching experience of over 19 years. She specializes in International Business, Economics and Banking.

Anita Daryal is a Chief Manager- Law, presently posted in Oriental Bank of Commerce, Delhi. She has an experience of 25 years in the recovery and law department of the Bank. 